\title{
Ethnologies
}

\section{Anne Marie Lane Jonah and Chantal Véchambre. French Taste in Atlantic Canada 1604 -1758: A Gastronomic History. (Sydney, NS: 2012, Cape Breton University Press. Pp. vii +251, ISBN 978-1-897009-77-2.)}

\section{Sarah J. Moore}

Volume 36, numéro 1-2, 2014

URI : https://id.erudit.org/iderudit/1037620ar

DOI : https://doi.org/10.7202/1037620ar

Aller au sommaire du numéro

Éditeur(s)

Association Canadienne d'Ethnologie et de Folklore

ISSN

1481-5974 (imprimé)

1708-0401 (numérique)

Découvrir la revue

Citer ce compte rendu

Moore, S. J. (2014). Compte rendu de [Anne Marie Lane Jonah and Chantal

Véchambre. French Taste in Atlantic Canada 1604 -1758: A Gastronomic History.

(Sydney, NS: 2012, Cape Breton University Press. Pp. vii +251, ISBN

978-1-897009-77-2.)]. Ethnologies, 36(1-2), 511-513.

https://doi.org/10.7202/1037620ar 


\section{COMPTE-RENDUS/REVIEWS}

Anne Marie Lane Jonah and Chantal Véchambre. French Taste in Atlantic Canada 1604 -1758: A Gastronomic History. (Sydney, NS: 2012, Cape Breton University Press. Pp. vii +251, ISBN 978-1-897009-77-2.)

As someone who appreciates cooking, reading cookbooks, and learning about Canadian history, it was with great excitement that I found French Taste in Atlantic Canada 1604-1758: A Gastronomic History. Jonah and Véchambre's book is an excellent example of how a book can be part historical research and part cookbook: the authors are able to retain the interest of the reader, yet it is not too disjointed as to interrupt the flow of the text. French Taste in Atlantic Canada does exactly that by examining the foodways of Acadie and Fortress Louisbourg during the $17^{\text {th }}$ and early $18^{\text {th }}$ centuries. The fully bilingual book is supplemented with contributions of essays and research by Ruby Fougère, a curator with Parks Canada; Alain Bossé, chef and culinary consultant; Heidi Moses, Archaeological Collections Manager; Robert Pichette, journalist; and Susan Lane, sommelier. Photography for the book was by Perry Jackson, with additional photography by Ruby Fougère and Heidi Moses. The book was translated and edited for French by Claudette Sirois-Strew and Monique Cantin.

One of the strengths of this book lies in the excellent summaries of the history of the fortified town of Louisbourg, the capital of the French colony of Île Royale (known today as Cape Breton and Prince Edward Island). The authors beautifully capture the daily life of the inhabitants of the colony of over 400 years ago, detailing, through archaeological and historical cultural research, how the encounters of the French (as well as Norman, Breton, Basque, Spanish, Portuguese and English) settlers with the Mi'kmaq created a unique and local cuisine. The book contains beautiful pictures of archeological artifacts, historical maps, and re-enactments of food preparation and the cuisine that would have been consumed at the Fortress Louisbourg National Historic Site. As noted in the Foreword by Alan Latourelle, Chief Executive Officer, Parks Canada, this book is an articulation of the livelihoods of those settlers, and how they used food as a tie to past generations. Therefore, it is a fitting publication as part of the celebration of the $300^{\text {th }}$ year anniversary of Louisbourg (2013). 
French Taste in Atlantic Canada is organized nicely into chapters detailing the history of Acadie (the first French colony in North America), to Louisbourg and the evolving tastes of seafood to gardening in the new colony. Later chapters discuss fine dining of the time, beverages, and finally desserts in the $18^{\text {th }}$ century. Each chapter includes essays on the historical evolution of the area, as well as discussions of and recipes for the foodstuffs, preparation, and meals that would have been prepared at the time. The book concludes with menus recreated from historical documents (journals, trade records, ship's records, personal accounts, and recipe books), a glossary of culinary vocabulary, and footnotes for each of the chapters. The book also contains a bibliography and an index. I found the bibliographic sources and footnotes to be especially useful for a reader who would like to do further research on the topic.

The recipes included in the text are indicative of the strong emphasis on seafood, such as Oyster Casserole and Eel Pie. Explanations of how these and other seafood (cod, salmon, and crab, to name a few) were prepared, as well as how they were eaten (from dining etiquette to utensils needed), make up a large portion of each chapter and are deftly described. The authors point out that they tried to choose recipes that would appeal to the modern tastes of the reader, and that they deliberately avoided expensive ingredients (although lamb, mutton, lobster, and truffles would have all been consumed by the French Regime in the $17^{\text {th }}$ and $18^{\text {th }}$ centuries). The recipes are easy to follow, instruction-wise, and while I did not attempt to make eel pie, I did try several other recipes with success. The authors helpfully reference an online app called "Heritage Gourmet" (which I found on the Google Play store after entering in the preface "Parks Canada") that offers further exploration of the foodways of Canada's culinary history.

Following the accounts of the lives of some of the first French settlers of Cape Breton was a wonderful way in which to bridge the gap between recipes and history. Descriptions of settlers make the gastronomic history come alive with detail. Some of the notable figures discussed are Nicolas Denys (a merchant born in France who saw the possibility of settlement in the new land from Samuel de Champlain's accounts), the Widow Plemarais (Marguerite de Sainte-Étienne de la Tour, who was widowed and re-married, and whose kitchen inventory is the only surviving documentation about kitchenware in an Acadian kitchen from the French era, documented in 1705) and Marie Marguerite Rose (Madame Laurent), a teenager in Africa who was sold into slavery and had come to Louisbourg with her army officer master. Marie Marguerite Rose eventually became emancipated, married a local Mi'kmaw man and became a successful innkeeper. The accounts 
of these people have been preserved through meticulous accounts on the part of Denys (who recorded many of his encounters of food sharing with the Mi'kmaq of the island), the written inventory of the Widow, and the records of the emancipation and inventory of Madame Laurent's inn (documented in 1757 in a letter from the High Court of the Admiralty, British Public Record Office). The level of detail used to describe these lives is extraordinary, and really adds to the book; the only problem is that I would have liked to see more of the sources that were used highlighted in-text as opposed to in footnote form (especially in regards to Madame Laurent, who the government of Canada has recognized as a person of national historic significance). Nonetheless, the research is documented carefully and explicitly.

French Taste in Atlantic Canada includes other excellent pieces. One chapter details the agriculture and gardening of the French in Acadia and Louisbourg and carefully examines the types of foodstuffs that were cultivated in the area. The book rightfully makes the distinction between the Acadians on the mainland of Nova Scotia, who were known for their successful farming, and the military-based, commercial society of Louisbourg, which was based on the fishery. Another chapter outlines a bill of lading for the King's Ship Hermione, which travelled from France to Île Royale and kept detailed records of the food served at the captain's table, a far cry from the rations designated for consumption by soldiers. The chapter on desserts discusses the first recorded Acadian recipe, which was recorded as a part of a legal document (the concession of a property at Port Royal, dated 1649). The "rent" due was a "Galette des rois," or a King's cake, a popular holiday tradition for the Feast of the Epiphany, and which still exists in various French-descendent places today.

French Taste in Atlantic Canada 1604 - 1758: A Gastronomic History is an informative and detailed examination of Acadian and Louisbourg foodways, with no glaring omissions or gaps in the history. Jonah and Véchambre, along with contributors Fougère and Pichette, write in an accessible manner, which makes the book appeal to many different audiences, whether a historian, a student, or a home cook. I appreciated the chapter layout of the book (laid out by history and meals), and while the recipes are good, the real strength of this book is how the writers were able to bring history and personal accounts together to show the contemporary reader the importance of food in the building of French colonies in Atlantic Canada. 